STUDIA I ARTYKU乇Y

\author{
Grzegorz Rutkowski
}

Muzeum Historii Polski

\title{
Środki pieniężne przerzucone drogą lotniczą dla Polskiego Państwa Podziemnego
}

\begin{abstract}
Abstrakt: Artykuł dotyczy odbioru przez ZWZ-AK środków finansowych przysyłanych wraz ze zrzutami lotniczymi. W tekście skupiam się na dynamice procesu przerzutu pieniędzy dla konspiracji w kraju oraz uwarunkowań odbioru środków finansowych przez ZWZ-AK. Podejmuję się także próby oceny wartości nabywczej środków przysłanych Polskiemu Państwu Podziemnemu, jak również procederu wymiany obcych walut na czarnym rynku oraz zakrojonej na szeroką skalę akcji fałszowania i wysyłania do kraju złotych okupacyjnych.
\end{abstract}

Słowa kluczowe: Polskie Państwo Podziemne, zrzuty lotnicze 1939-1945, finanse.

Abstract: The article describes the receipt of airdropped financial means by the Union of Armed Struggle-Home Army (ZWZ-AK). I focus mainly on the dynamics of the process of airdropping for the Polish Underground State and the circumstances of receipt of those money by the ZWZ-AK. I also attempt to assess both the purchasing power of money sent to the Polish Underground State, and foreign currency trading on the black market, together with a broadscale action of forging occupation money and sending it to Poland under the occupation.

Key w or d s: Polish Underground State, Airdrops 1939-1945, finances.

„Żeby prowadzić wojnę potrzeba trzech rzeczy: pieniędzy, pieniędzy i pieniędzy". Słowa wypowiedziane przez Napoleona Bonaparte celnie opisuja znaczenie środków pieniężnych dla prowadzenia działań wojennych w każdej epoce. Armia potrzebuje pieniędzy na zakupy środków walki, aprowizację, uposażenie żołnierzy itd. Nie inaczej było w wypadku Armii Krajowej. Pod okupacją znacznie komplikowały się pozyskiwanie oraz gospodarowanie środkami finansowymi. ZWZ-AK i cywilne struktury podziemia mogły liczyć 
na wsparcie finansowe od władz polskich na obczyźnie. Przesyłanie środków pieniężnych dla $\mathrm{AK}$ z zachodu było trudnym i czasochłonnym zadaniem. Od lutego 1941 r. pojawiła się nadzieja na znaczącą poprawę zaopatrzenia finansowego Podziemia. Od tego okresu pieniądze dla AK i Delegatury Rządu zaczęły spadać z nieba wraz ze zrzutami lotniczymi. Niniejszy tekst będzie próbac przedstawienia zakresu pomocy finansowej, jaką uzyskało Polskie Państwo Podziemne z przerzutów powietrznych ${ }^{1}$.

Biorąc pod uwagę wpływ pomocy finansowej z zachodu na kształt polskiego podziemia, nie dziwi fakt, że ta problematyka była już podejmowana przez badaczy. W większości przypadków ukazywano całościowy zakres pomocy udzielonej Polskiemu Państwu Podziemnemu². Na uznanie zasługują badania Waldemara Grabowskiego, który podjął się szczegółowego przedstawienia zakresu pomocy finansowej, jaka przypadła $\mathrm{DR}^{3}$. Godną odnotowania wartość poznawczą posiada również artykuł Krzysztofa Stolińskiego, w którym autor skupił się na procederze produkcji i dostarczenia do kraju sfałszowanych złotych okupacyjnych (tzw. młynarek) ${ }^{4}$. Natomiast Bartłomiej Szyprowski poddał analizie przypadki utraty pieniędzy przekazanych w poszczególnych zrzutach ${ }^{5}$.

Zagłębiajac się w lekturze wymienionych powyżej tekstów, spostrzeżemy, że mamy do czynienia z bardzo delikatna materia. Studiując zachowane archiwalia, badacz zajmujący się tą problematyką natrafi na pewne rozbieżności co do wielkości przerzucanych kwot pieniędzy. Pewne drobne różnice dotyczą również globalnych kwot przerzuconych dla AK i DR w poszczególnych okresach (zob. tabela 1 i wykres 1 ).

${ }^{1}$ Pragnę podziękować Fundacji Armii Krajowej im. Franciszka Miszczaka oraz The Polonia Aid Foundation Trust (PAFT) za wsparcie w prowadzeniu kwerend zagranicznych.

${ }^{2}$ Zakres pomocy udzielonej ZWZ-AK i DR tą drogą znamy już od lat pięćdziesiątych XX w. (Polskie Sity Zbrojne w drugiej wojnie światowej, t. III: Armia Krajowa, Londyn 1950, s. 346, 401-406). Czytelnicy w Polsce mogli się zapoznać z tymi danymi za sprawą badań Jędrzeja Tucholskiego (J. Tucholski, Cichociemni, wyd. 3, Warszawa 1988, s. 129, 140, 151, 179).

${ }^{3}$ Autor przedstawił wykaz sum pieniędzy przysyłanych przez każdego kuriera DR (W. Grabowski, Delegatura Rzqdu Rzeczypospolitej Polskiej na Kraj, Warszawa 1995, s. 50-59). Natomiast w późniejszym artykule znacznie poszerzył stan naszej wiedzy w tym zakresie (idem, Niedoreczona poczta. Zrzuty lotnicze (finansowe i materiałowe) dla Delegatury Rzadu na Kraj, w: Żołnierzowi Niepodległej. Księga dedykowana śp. gen. Mieczysławowi Huchli, red. T. Balbus i in., Rzeszów 2012, s. 64-95).

${ }^{4}$ K. Stoliński, Pomoc finansowa dla Armii Krajowej i Delegatury Rzadu na Kraj (1940-1944), „Mars” 2004, t. XVI, s. 5-14.

${ }_{5}$ B. Szyprowski, Kradzież pieniędzy cichociemnych z placówki „Pole” pod Wyszkowem. Wyrok Wojskowego Sadu Specjalnego na Wtadystawa Wysockiego, „Rocznik Wołomiński” 2011, t. VII, s. 211-227; idem, Porucznik cc. Witold Strumpf „Sud” przed sqdem podziemia, „Przegląd Historyczno-Wojskowy” 2012, nr 2 (240), s. 207-218; idem, Sprawa kradzieży pieniędzy cichociemnych z placówki „Trawa” i rozwiazanie jej przez podziemny wymiar sprawiedliwości, „Przegląd Historyczno-Wojskowy” 2015, nr 1 (251), s. 158-178; idem, Sprawy sqdowe zwiazane z mieniem zrzucanym dla Sit Zbrojnych w Kraju droga lotnicza, „Zgrupowanie Radosław” 2011, nr 5, s. 73-86. 
Tabela 1. Zestawienie kwot wysłanych do kraju drogą lotniczą wedle poszczególnych sprawozdań Oddziału VI Sztabu Naczelnego Wodza (NW)

\begin{tabular}{|l|l|l|}
\hline $\begin{array}{l}\text { Sezon } \\
\text { operacyjny }\end{array}$ & $\begin{array}{l}\text { Dane wedle sprawozdania Oddziału } \\
\text { VI Sztabu NW (1941-1945) }\end{array}$ & $\begin{array}{l}\text { Dane wedle zestawień i sprawozdań } \\
\text { Oddziału VI Sztabu NW z sezonów } \\
\text { operacyjnych }^{8}\end{array}$ \\
\hline $\begin{array}{l}\text { Okres } \\
\text { próbny }\end{array}$ & $\begin{array}{l}1541450 \text { USD; } 119400 \text { USD złotych; } \\
1775 \text { funt złotych; } 10000 \text { peset }^{9}\end{array}$ & $\begin{array}{l}1541450 \text { USD; } 119400 \text { USD }^{7} \text { złotych }^{10} ; \\
1175 \text { tys. funtów złotych; } 885 \text { tys. RM }^{0}\end{array}$ \\
\hline Intonacja & 10022000 USD; 2158000 RM & $\begin{array}{l}13022000 \text { USD; } 5158000 \text { RM; } 10000 \\
\text { Peset; } 700000 \text { tys. złotych }\end{array}$ \\
\hline Riposta & $\begin{array}{l}11207300 \text { USD; } 161025 \text { USD złotych; } \\
1000000 \text { RM; } 40169000 \text { młynarek }\end{array}$ & $\begin{array}{l}15948300 \text { USD; } 161025 \text { USD złotych; } \\
6986500 \text { RM, } 1644 \text { funtów w złocie, } \\
40569800 \text { młynarek }\end{array}$ \\
\hline Odwet & $\begin{array}{l}3143400 \text { USD; } 34800 \text { USD złotych; } \\
420000 \text { RM }\end{array}$ & $\begin{array}{l}3996188 \text { tys. USD; } 34800 \text { tys. USD } \\
\text { w złocie; } 6460000 \text { RM }\end{array}$ \\
\hline
\end{tabular}

W zachowanym materiale źródłowym natrafiamy na ślady świadczące o rozbieżnościach sum awizowanych dla Podziemia ze stanem faktycznym. W czerwcu 1942 r. ppłk Michał Protasewicz „Rawa” informował KG AK: „Niezrozumiałe są dla mnie braki i nadwyżki w poszczególnych puszkach, które były ładowane protokolarnie po parokrotnym przeliczeniu pieniędzy"12. W październiku 1942 r. KG meldowała o niezgodności zawartości zrzuconych pasów ze spisami na placówkach odbiorczych „Róg” (1/2 IX 1942), „Igła” (1/2 IX 1942), „Żaba” (3/4 IX 1942), „Ugór” (3/4 IX 1942), „Zamek” (1/2 X 1942)².

${ }^{6}$ Zestawienia kwot pieniędzy przerzucanych drogą lotniczą do Polski nie odpowiadały okresom budżetowym. Taki stan rzeczy był podyktowany technicznymi możliwościami lotów. Zrzuty wykonywano od jesieni do wiosny, gdy długość nocy pozwalała na przelot do Polski (tzw. sezony operacyjne). W czasie wojny zrealizowano cztery takie sezony: „Próbny” (II 1941 - IV 1942), „Intonacja” (IX 1942 - III 1943), „Riposta” (IX 1943 VII 1944), „Odwet” (VIII-XII 1944).

7 Polskie Sity Zbrojne..., s. 346.

8 J. Tucholski, op. cit., s. 129, 140, 151, 179; Polskie Sity Zbrojne..., s. 401-406.

${ }^{9}$ Wymieniona w zestawieniu kwotę 10 tys. peset zrzucono na kosz „Olcha” 13/14 III 1943 r., czyli w sezonie „Intonacja” (Archiwum Akt Nowych, Armia Krajowa, 203/I-14, k. 33).

${ }^{10} \mathrm{~W}$ zestawieniu opracowanym przez Komisję Historyczną b. Sztabu Generalnego została podana łączna kwota dolarów papierowych i złotych - 1660850 dolarów (Polskie Sity Zbrojne..., s. 401).

${ }^{11} \mathrm{~W}$ zestawieniu opracowanym przez Komisję Historyczna b. Sztabu Generalnego nie wskazano kwoty 700 tys. zł (ibidem, s. 404). Do Polski wysłano w tym sezonie do 700 tys. fałszywych złotych (co zostało opisane w dalszej części tekstu), jednak z uwagi na słaba jakość wykonania podrobionych banknotów nie zostały one wprowadzone do obiegu. Sztab NW nie potraktował tej kwoty jako dotacji dla AK.

12 Organizacja wysytki i odbioru zrzutów materiatowych dla Armii Krajowej w wybranych dokumentach, wybór i oprac. J. Tarczyński, Londyn 2001, s. 73.

${ }^{13}$ Wojskowe Biuro Historyczne (dalej: WBH), Oddział VI Sztabu Głównego Naczelnego Wodza (dalej: OVI), II.52.565, Depesza Kaliny nr 871 z 21 X 1942, k. 74; ibidem, Depesza Kaliny nr 853 z 15 X 1942, k. 57. 
Wykres 1. Kwoty pieniędzy różnych walut (w tys.) przerzuconych drogą lotniczą do kraju wedle sprawozdań Sztabu NW z poszczególnych sezonów operacyjnych ${ }^{14}$

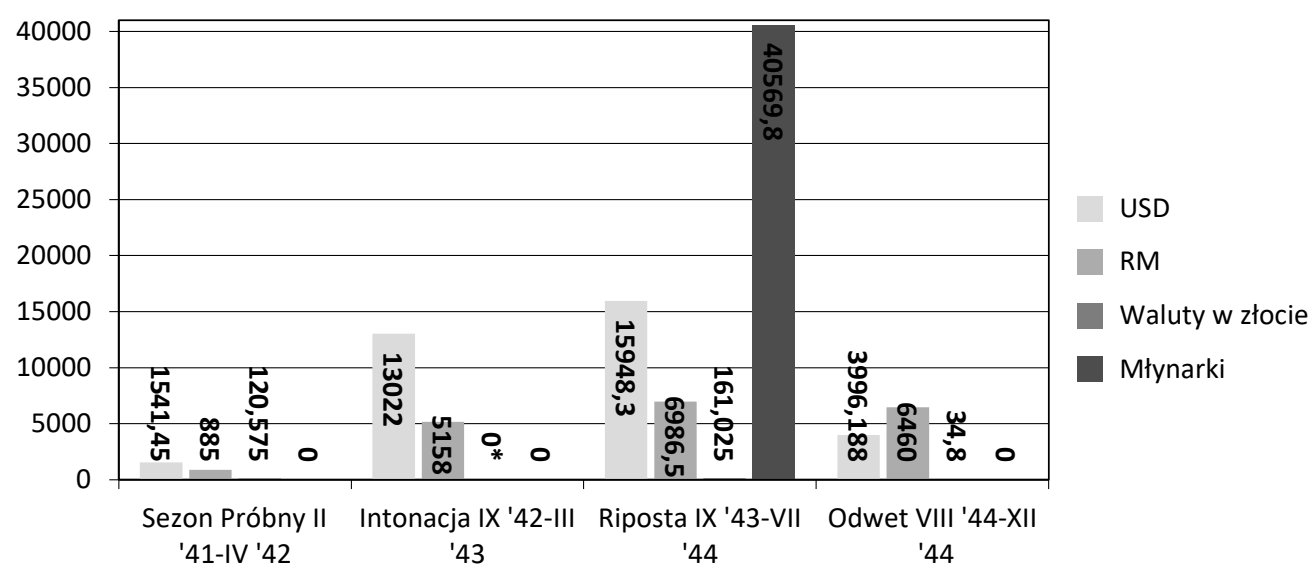

Podobna sytuacja miała miejsce $\mathrm{w}$ kwietniu 1942 r. ${ }^{15}$ Zamieszanie było potęgowane przez potrzeby ewakuacji i odbioru zrzutów. Przeprowadzenie ewakuacji niekiedy narzucało konieczność rozrywania bądź dzielenia pasów ${ }^{16}$. Jesienia 1942 r. dochodziło do przypadków liczenia zawartości pasów wkrótce po zrzucie oraz przewożenia osobistych pieniędzy skoczków w kieszeniach pasów z pieniędzmi dla AK i DR ${ }^{17}$. Wiosną 1943 r. zrzucano również pieniądze w bagażniku skoczków, co utrudniało ewakuację środków ze zrzutowiska ${ }^{18}$. Tytułem wyjaśnienia warto nadmienić, że skoczkowie prócz środków przeznaczonych dla DR i AK przewozili pieniądze prywatne oraz diety wypłacane na podróż w kraju ${ }^{19}$. W sezonie operacyjnym „Riposta” część pieniędzy dla DR została zrzucona w paczkach bez znaków awiza. Zrzutów takich dokonano na kosze „Obraz” (16/17 IV 1944), „Mysz” (12/13 IV 1944), „Przycisk”

${ }^{14} \mathrm{Z}$ uwagi na przejrzystość tabeli zsumowano liczbę przerzuconych walut w złocie (ich wartość bazowała głównie na wartości kruszcu, z którego wykonano monety). Pominięto również kwotę 10 tys. hiszpańskich peset zrzuconych w sezonie „Intonacja”.

${ }^{15}$ WBH, OVI, II.52.555, Depesza Kaliny nr 322 z 21 IV 1942 r., k. 15.

16 WBH, OVI, II.52.565, Depesza Kaliny nr 806 z 2 X 1942 r., k. 7.

17 Ibidem.

18 Studium Polski Podziemnej w Londynie (dalej: SPP), Oddział VI Sztabu Naczelnego Wodza (dalej: OVI), A421, k. 177.

${ }_{19}$ Przy odprawie skoczka wypłacano jego sześciomiesięczne uposażenie. Ustalono także środki na podróż w kraju, zabierane przez skoczków (40 USD, 500 zł, 100 RM). Zaliczka podróżna podlegała rozliczeniu po skoku (SPP, OVI, A420, k. 63). Biorąc pod uwagę liczbę żołnierzy delegowanych przez Sztab NW, te kwoty w nieznaczny sposób mogły wpłynąć na zakres zaopatrzenia kraju (do 12 tys. USD, 15 tys. zł, 30 tys. RM, odliczając od tego środki, które skoczkowie wydali na podróż po GG). 
(16/17 IV 1944), „Kanapa” (16/17 IV 1944) ${ }^{20}$. To wszystko utrudniało zweryfikowanie, czy przerzucone sumy dotarły do odbiorców w całości.

Przedstawienie, kiedy i jakie kwoty zostały przerzucone do Polski, w rozbiciu na poszczególne miesiące okupacji, posiada znaczne walory poznawcze. Zwłaszcza w przypadku ZWZ-AK, która jak dotąd nie doczekała się podobnego zestawienia $^{21}$. Zebrane przeze mnie dane zostały zamieszczone w tabeli 2.

Tabela 2. Środki pieniężne przerzucone w poszczególnych miesiącach akcji zrzutowej ${ }^{22}$

\begin{tabular}{|c|c|c|c|c|c|}
\hline & $\begin{array}{c}\text { Rok } \\
\text { i miesiąc }\end{array}$ & $\begin{array}{c}\text { Przerzucone } \\
\text { kwoty } \\
\text { dla ZWZ-AK }\end{array}$ & $\begin{array}{c}\text { Przerzucone } \\
\text { kwoty } \\
\text { dla DR }\end{array}$ & $\begin{array}{c}\text { Lącznie } \\
\text { przerzucono } \\
\text { do kraju }\end{array}$ & 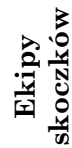 \\
\hline \multirow{3}{*}{$\vec{F}$} & Luty & 154,331 tys. USD & $\begin{array}{l}34,9 \text { tys. RM, } \\
100 \text { tys. zł }\end{array}$ & $\begin{array}{l}154,331 \text { tys. USD, } 34,9 \\
\text { tys. RM, } 100 \text { tys. zł }\end{array}$ & 1 \\
\hline & Listopad & 30 tys. USD & \begin{tabular}{|l|}
12 tys. USD, \\
170 tys. RM \\
\end{tabular} & $\begin{array}{l}42 \text { tys. USD, } \\
170 \text { tys. RM } \\
\end{array}$ & 1 \\
\hline & Grudzień & 97,2 tys. USD & $\begin{array}{l}43,7 \text { tys. USD, } \\
240 \text { tys. RM }\end{array}$ & $\begin{array}{l}140,9 \text { tys. USD, } \\
240 \text { tys. RM }\end{array}$ & 1 \\
\hline \multirow{3}{*}{$\begin{array}{c}\mathcal{N} \\
\text { ปे } \\
\text { - }\end{array}$} & Styczeń & 99,9 tys. USD & $\begin{array}{l}120-150 \text { tys. } R M \\
0-16,5 \text { tys. } \mathrm{USD}^{23}\end{array}$ & $\begin{array}{l}\text { 99,9-116, } 4 \text { tys. USD, } \\
120-150 \text { tys. RM }\end{array}$ & 1 \\
\hline & Marzec & $\begin{array}{l}1059,75 \text { tys. USD, } \\
49,68 \text { tys. USD złotych, } \\
1,775 \text { tys. GBR złotych, } \\
185 \text { tys. RM }\end{array}$ & $\begin{array}{l}\text { 189,5-309,5 tys. USD, } \\
0,9-1,2 \text { tys. USD } \\
\text { złotych, } 0,075-0,1 \text { GBR } \\
\text { złotych, } 330-730 \text { tys. } \\
\text { RM }^{24}\end{array}$ & $\begin{array}{l}\text { 1249,25-1369,25 tys. } \\
\text { USD, 50,58-50,88 USD } \\
\text { w złocie, } 1,85-1,875 \\
\text { tys. GBR w złocie, } \\
515-915 \text { tys. RM }\end{array}$ & 5 \\
\hline & Kwiecień & $\begin{array}{l}414 \text { tys. USD, } 38,4 \text { tys. } \\
\text { USD złotych }\end{array}$ & Brak & $\begin{array}{l}414 \text { tys. USD, } 38,4 \text { tys. } \\
\text { USD złotych }\end{array}$ & 1 \\
\hline
\end{tabular}

${ }^{20}$ WBH, OVI, II.52.29, Depesza Lawiny nr 813 z 3 V 1944 r., k. 45.

${ }^{21}$ Zestawienie środków wysłanych dla DR zostało dokonane przez Grabowskiego w przytaczanych wyżej jego pracach.

${ }^{22} \mathrm{Na}$ podstawie: WBH, OVI, II.52.31, k. 26; WBH, OVI, II.52.545, k. 66-67; WBH, OVI, II.52.559, k. 38; WBH, OVI, II.52.565, k. 57; WBH, OVI, II.52.615, k. 51, 176, 187, 188, 217; SPP, OVI, A143; SPP, OVI, A420, k. 200, 202, 203; K. Bieniecki, Lotnicze wsparcie Armii Krajowej, Kraków 1994; W Grabowski, Delegatura...; idem, Niedoręczona...; J. Tucholski, op. cit.

${ }^{23}$ Rozbieżności co do kwot w zrzucie 6/7 I 1942 r.: wedle Waldemara Grabowskiego (Niedoręczona..., s. 68-69) przerzucono dla DR 120 tys. RM, 16,5 tys. USD lub 135 tys. RM i 16,5 tys. USD lub 150 tys. RM. Wedle depeszy nr 2085 Rawy z 9 VI 1942 r. zrzucono 150 tys. RM (Organizacja wysytki $i$ odbioru zrzutów materiałowych dla Armii Krajowej w wybranych dokumentach, wybór i oprac. J. Tarczyński, Londyn 2001, s. 74). Większość pieniędzy (3/4) utracono po zrzucie - rozkradzione przez chłopów (SPP, OVI, A420, k. 200).

${ }^{24}$ Rozbieżności co do kwot przerzuconych w zrzucie 3/4 III 1942 r.: wedle Kajetana Bienieckiego (op. cit., s. 37) było to 147 tys. USD, 6 tys. USD w złocie i 185 tys. RM. Potwierdza to meldunek Oddziału VI Sztabu NW (WBH, OVI, II.52.615, k. 217), a także ustalenia Bartłomieja Szyprowskiego (Kradzież..., s. 214). Wedle meldunku nr 111 płk. Tadeusza Rudnickiego do NW z 4 III 1942 r. kwoty zrzucone wynosiły 149 tys. USD i 6 tys. USD 


\begin{tabular}{|c|c|c|c|c|c|}
\hline & $\begin{array}{c}\text { Rok } \\
\text { i miesiąc }\end{array}$ & $\begin{array}{l}\text { Przerzucone } \\
\text { kwoty } \\
\text { dla ZWZ-AK }\end{array}$ & $\begin{array}{l}\text { Przerzucone } \\
\text { kwoty } \\
\text { dla DR }\end{array}$ & $\begin{array}{l}\text { Łącznie } \\
\text { przerzucono } \\
\text { do kraju }\end{array}$ & 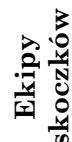 \\
\hline \multirow[t]{2}{*}{$\stackrel{2}{2}$} & Wrzesień & $\begin{array}{l}629,1 \text { tys. USD, } \\
44,8 \text { tys. USD złotych, } \\
1 \text { tys. RUS złotych, } \\
970 \text { tys. RM }\end{array}$ & $\begin{array}{l}2 \text { pasy z pieniędzmi } \\
\text { i } 3 \text { puszki ze złotem, } \\
\text { oraz } 915 \text { tys. } R M\end{array}$ & $\begin{array}{l}629,1 \text { tys. USD, } \\
44,8 \text { tys. USD złotych, } \\
1 \text { tys. RUS złotych, } \\
1885 \text { tys. RM }\end{array}$ & 4 \\
\hline & Październik & 945,3 tys. USD & 859 tys. RM & $\begin{array}{l}945,3 \text { tys. USD, } 859 \\
\text { tys. RM }\end{array}$ & 4 \\
\hline \multirow{2}{*}{$\stackrel{n}{\mathscr{f}}$} & Styczeń & $\begin{array}{l}903 \text { tys. USD, } 180 \text { tys. } \\
\text { RM }\end{array}$ & $\begin{array}{l}\text { 135- } 349,4 \text { tys. USD, } \\
0,4-1,28 \text { tys. USD zło- } \\
\text { tych, } 0,045-0,235 \text { GBR } \\
\text { złotych, } 35 \text { tys. } \mathrm{RM}^{25} \\
\end{array}$ & $\begin{array}{l}\text { 1038- } 1252,4 \text { tys. USD, } \\
0,4-1,28 \text { tys. USD zło- } \\
\text { tych, } 0,045-0,235 \text { GBR } \\
\text { złotych, } 215 \text { tys. RM } \\
\end{array}$ & 3 \\
\hline & Luty & $\begin{array}{l}2111 \text { tys. USD, } 270 \\
\text { tys. RM }\end{array}$ & $\begin{array}{l}289-356 \text { tys. USD, } \\
0,48-0,8 \text { tys. USD } \\
\text { złotych, } 0,135-0,18 \\
\text { GBR złotych }{ }^{26}\end{array}$ & $\begin{array}{l}2400-2467 \text { tys. USD; } \\
0,48-0,8 \text { tys. USD zło- } \\
\text { tych, } 0,135-0,18 \text { GBR } \\
\text { złotych, } 270 \text { tys. RM }\end{array}$ & 8 \\
\hline
\end{tabular}

w złocie (Organizacja..., s. 66). Po zrzucie obecny przy akcji delegat KG, por. Władysław Wysocki „Leon” dopuścił się defraudacji części pieniędzy ze zrzutu (zob. B. Adamecki, Lotnictwo Armii Krajowej. Zarys historyczny działania Sztabu lotniczego w ramach ZWZ i Armii Krajowej w latach 1940-1944, w: H. Szołdrska, Lotnictwo Armii Krajowej, Poznań 1998, s. 352; B. Szyprowski, Kradzież...). KG AK meldowała brak 67155 USD i 3020 złotych USD. DR informowała o braku 15 tys. RM (SPP, OVI, A420, k. 203). Wedle Szyprowskiego „Leon” ukradł 78 tys. USD papierowych i 3 tys. USD w złocie (B. Szyprowski, Kradzież..., s. 215, 223). Dodatkowo AK meldowała o zagubieniu bądź kradzieży 5 pistoletów skoczków (SPP, OVI, A420, k. 203). Zrzucony podczas tego lotu Stanisław Jankowski w swoich wspomnieniach podał, że rzeczy osobiste skoczków, 4 pistolety oraz część pieniędzy (2 pasy z USD w złocie i puszki z USD papierowymi) zostały przerzucone do Warszawy przez personel zrzutowiska (S. Jankowski, $Z$ fatszywym ausweisem $w$ prawdziwej Warszawie, t. I, wyd. 3, Warszawa 1988, s. 289). Ze zrzutu 30/31 III 1942 r. ekipa „Mira” utraciła część pieniędzy - 28 tys. USD i 100 USD złotych (SPP, OVI, A420, k. 202; WBH, OVI, II.52.559, k. 38). Rozbieżności co do ilości waluty w złocie zrzuconej 30/31 III 1942 r. wraz z ekipa „Gotura” (WBH, OVI, II.52.615, k. 176; SPP, OVI, A143, k. 50).

${ }^{25}$ Rozbieżności co do środków dostarczonych w zrzucie ekipy „Rudego” i „Młota” (zrzuty 25/26 I 1943): Grabowski podał, że w przypadku tego pierwszego zrzutu DR dostarczono 220 tys. USD, 800 USD złotych, 145 funt złotych (W. Grabowski, Niedoręczona..., s. 70-71). Natomiast w starszej publikacji wskazywał 80 tys. USD i 400 USD złotych (idem, Delegatura..., s. 52). Ten sam autor w przypadku ekipy „Maka” podał kwoty 129,4 tys. USD, 35 tys. RM, 90 funtów złotych, 480 USD złotych lub 82,4 tys. USD, 90 funtów złotych, 35 tys. RM (idem, Niedoręczona..., s. 70, 71). W starszej publikacji tego autora natrafiamy na jeszcze inną kwotę dla DR przewożoną przez tę ekipę - 35 tys. RM, 55 tys. USD, 45 funtów złotych, 480 USD złoto (idem, Delegatura..., s. 52).

${ }^{26}$ Jeden pas DR zagubiony po zrzucie (ibidem, s. 70). W czasie ewakuacji zrzutu z placówki „Koń” (16/17 II 1943) utracono 81 tys. USD DR i 315 tys. USD AK (K. Bieniecki, op. cit., s. 58; W. Grabowski, Niedoręczona..., s. 70; J. Tucholski, op. cit., s. 145). Istnieją rozbieżności co do środków przerzuconych przez ekipy „Lisa” i „Spokojnego” (obie zrzucone 16/17 II 1943) dla DR. $\mathrm{Z}$ tą pierwszą dostarczono 93 tys. USD, 45 funtów złotych, 480 USD złotych (W. Grabowski, 
Środki pieniężne przerzucone drogą lotniczą dla Polskiego Państwa Podziemnego 11

\begin{tabular}{|c|c|c|c|c|c|}
\hline & $\begin{array}{c}\text { Rok } \\
\text { i miesiąc }\end{array}$ & $\begin{array}{c}\text { Przerzucone } \\
\text { kwoty } \\
\text { dla ZWZ-AK }\end{array}$ & $\begin{array}{l}\text { Przerzucone } \\
\text { kwoty } \\
\text { dla DR }\end{array}$ & $\begin{array}{c}\text { Lącznie } \\
\text { przerzucono } \\
\text { do kraju }\end{array}$ & 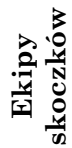 \\
\hline \multirow{3}{*}{ 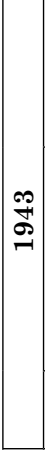 } & Marzec & $\begin{array}{l}4805 \text { tys. USD, } 10 \text { tys. } \\
\text { peset, } 673 \text { tys. RM }\end{array}$ & $\begin{array}{l}\text { 584,7 tys. USD i } 0,195 \\
\text { tys. GBR w złocie }\end{array}$ & $\begin{array}{l}5389,7 \text { tys. USD, } \\
0,195 \text { tys. GBR } \\
\text { w złocie, } 10 \text { tys. peset, } \\
673 \text { tys. } \mathrm{RM}^{27}\end{array}$ & 9 \\
\hline & Wrzesień & $\begin{array}{l}2695,5 \text { tys. USD, } \\
1,425 \text { tys. USD } \\
\text { w złocie, } 2,8 \text { tys. RM } \\
\text { złotych i } 0,24 \text { tys. RUS } \\
\text { złocie, } 920 \text { tys. RM }\end{array}$ & $\begin{array}{l}443 \text { tys. USD, } \\
0,12 \text { tys. GBR złotych, } \\
180 \text { tys. RM }\end{array}$ & $\begin{array}{l}3138,8 \text { tys. USD, } \\
1,425 \text { tys. USD } \\
\text { w złocie, } 0,12 \text { tys. GBR } \\
\text { złotych, } 2,8 \text { tys. RM } \\
\text { złotych i } 0,24 \text { tys. RUS } \\
\text { złocie, } 1100 \text { tys. } \text { RM }^{28}\end{array}$ & 9 \\
\hline & Październik & $\begin{array}{l}216 \text { tys. USD, } \\
80 \text { tys. RM }\end{array}$ & 174 tys. USD & $\begin{array}{l}390 \text { tys. USD, } \\
80 \text { tys. RM }\end{array}$ & 1 \\
\hline \multirow{3}{*}{ 矛 } & kwiecień & $\begin{array}{l}\text { 4634,9 tys. USD, } \\
\text { 45,6 tys. USD złotych }\end{array}$ & $\begin{array}{l}1622-3196 \text { tys. USD, } \\
0,060-0,105 \text { tys. GBR } \\
\text { w złocie, } 0-0,045 \text { USD } \\
\text { w złocie, } 4316 \text { tys. RM, } \\
0-150 \text { tys. } \text { zł }^{29}\end{array}$ & $\begin{array}{l}6256,9-7830,9 \text { tys. } \\
\text { USD, } 45,6-45,645 \\
\text { tys. USD w złocie, } \\
0,060-0,105 \text { tys. GBR } \\
\text { w złocie, } 4316 \text { tys. RM, } \\
0-150 \text { tys. zł }\end{array}$ & 15 \\
\hline & Maj & $\begin{array}{l}\text { m.in. } 951 \text { tys. USD, } \\
\text { 99,6 USD w złocie }{ }^{30}\end{array}$ & $\begin{array}{l}\text { 650-1172 tys. USD, } \\
0-59 \text { GBR w złocie, } \\
\text { sztabka złota, } 800- \\
1150 \text { tys. } \text { RM }^{31}\end{array}$ & $\begin{array}{l}\text { m.in. } 1601-2123 \text { tys. } \\
\text { USD, } 99,6 \text { USD w zło- } \\
\text { cie, 0-0,059 tys. GBR } \\
\text { w złocie, sztabka złota, } \\
800-1150 \text { tys. RM }\end{array}$ & 9 \\
\hline & Lipiec & $\begin{array}{l}444,9 \text { tys. USD, } \\
14,4 \text { tys. USD złoto, } \\
260 \text { tys. RM }\end{array}$ & $160-260$ tys. USD ${ }^{32}$ & $\begin{array}{l}604,9-704,9 \text { tys. USD, } \\
14,4 \text { tys. USD złoto, } \\
260 \text { tys. RM }\end{array}$ & 2 \\
\hline
\end{tabular}

Delegatura..., s. 52) lub 140 tys. USD, 45 funtów złotych, 480 USD złotych (idem, Niedoręczona..., s. 70, 71). Z ekipa „Spokojnego” zrzucono 81 tys. USD, 90 funtów złotych (idem, Niedoręczona..., s. 70.) lub 81 tys. USD i 1000 funtów złotych (idem, Delegatura..., s. 52).

27450 tys. USD utraconych w czasie zrzutu ekipy „Suda” (13/14 III 1943). Zob. B. Szyprowski, Porucznik cc. Witold Strumpf „Sud”..., s. 217.

28 Jan Jaźwiński, szef Wydziału S Oddziału VI (Specjalnego) Sztabu NW, organizujący loty do Polski, w swoich wspomnieniach podał kwoty przerzucone we wrześniu 1943 r.: 312700 USD, 1459 złotych USD, 2800 RM i 240 złotych rubli (J. Jaźwiński, Dramat dowódcy. Pamiętnik oficera sztabu oddziału wywiadowczego $i$ specjalnego, t. I: Czerwiec 1905 - Styczeń 1944, Montreal 2012, s. 480).

${ }^{29}$ Rozbieżności co do kwot pieniędzy dostarczonych wraz z ekipa „Salamandra” (3/4 IV 1944), „Cozasia” (8/9 IV 1944), „Osy” (9/10 IV 1944), „Aminiusa” (12/13 IV 1944).

${ }^{30}$ Brak danych co do części środków (dolarów papierowych) dla AK, dostarczonych wraz z ekipa „Doiliny-2” (4/5 V 1944) oraz ekipa „Lewara” (10/11 V 1944), „Siły” (19/20 V 1944), „Zgody-2” (21/22 V 1944), „Harpuna” (24/25 V 1944), „Rysia-2” (30/31 V 1944).

31 Rozbieżności co do kwot pieniędzy dostarczonych wraz z ekipami: „Siły” (19/20 V 1944), „Harpuna” (24/25 V 1944).

${ }^{32}$ Rozbieżności co do kwot dostarczonych DR wraz z ekipa „Topora-2” (30/31 VII 1944) (W. Grabowski, Niedoręczona..., s. 74, 75, 78). 


\begin{tabular}{|c|c|c|c|c|c|}
\hline & $\begin{array}{c}\text { Rok } \\
\text { i miesiąc }\end{array}$ & $\begin{array}{l}\text { Przerzucone } \\
\text { kwoty } \\
\text { dla ZWZ-AK }\end{array}$ & $\begin{array}{l}\text { Przerzucone } \\
\text { kwoty } \\
\text { dla DR }\end{array}$ & $\begin{array}{l}\text { Lącznie } \\
\text { przerzucono } \\
\text { do kraju }\end{array}$ & 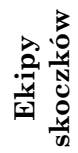 \\
\hline \multirow{5}{*}{ 亲 } & Sierpień & Brak & 250 tys. RM & 250 tys. $\mathrm{RM}$ & 0 \\
\hline & Wrzesień & $\begin{array}{l}303 \text { tys. USD, } 3,6 \text { tys. } \\
\text { USD złote, } 250 \text { tys. } \\
\text { RM, } 3920 \text { tys. PLN }\end{array}$ & Brak & $\begin{array}{l}303 \text { tys. USD, } 3,6 \text { tys. } \\
\text { USD złote, } 250 \text { tys. } \\
\text { RM, } 3920 \text { tys. PLN }\end{array}$ & 1 \\
\hline & Październik & $\begin{array}{l}\text { 1072,8 tys. USD, } 14,4 \\
\text { tys. USD złotych }\end{array}$ & Brak & $\begin{array}{l}\text { 1072,8 tys. USD, } \\
14,4 \text { tys. USD złotych }\end{array}$ & 2 \\
\hline & Listopad & $\begin{array}{l}817,588 \text { tys. USD, } 7,2 \\
\text { tys. złotych USD }\end{array}$ & $\begin{array}{l}852,788 \text { tys. USD } \\
\text { i } 1140-1540 \text { tys. } \text { RM }^{33}\end{array}$ & $\begin{array}{l}\text { 1670,376 tys. USD, } \\
7,2 \text { tys. złotych USD, } \\
1140-1540 \text { tys. RM }\end{array}$ & 2 \\
\hline & Grudzień & $\begin{array}{l}589,8 \text { tys. USD, } \\
6 \text { tys. złotych USD }\end{array}$ & 1140 tys. RM & $\begin{array}{l}589,8 \text { tys. USD, } \\
6 \text { złotych USD, } \\
1140 \text { tys. RM }\end{array}$ & 1 \\
\hline
\end{tabular}

Potrzeby finansowe Polskiego Państwa Podziemnego rosły w postępie geometrycznym. W $1941 \mathrm{r}$. budżet ZWZ został oszacowany na 517 tys. USD $^{34}$. W 1942 r. wydatki początkowo określono na 2,7 mln USD, by później zwiększyć je na kwotę ponad 4 mln USD ${ }^{35}$. W 1943 r. wielkość budżetu AK wzrosła do 10 mln USD i podwoiła się do 20 mln USD w $1944 \mathrm{r} .{ }^{36}$ Natomiast budżet DR z 1943 r. wynosił 5,724 mln USD, a w 1944 r. został oszacowany na $12 \mathrm{mln} \mathrm{USD}^{37}$. Przerzut pieniędzy kształtował się na różnym poziomie w poszczególnych okresach (zob. wykresy 1 i 2 ).

Na podstawie dwóch powyższych wykresów dostrzeżemy, że najwięcej pieniędzy dostarczono w sezonie operacyjnym „Riposta”. W sezonie operacyjnym „Odwet” wykonano więcej zrzutów (227), jednak 214 z nich było kierowane na Warszawę w czasie powstania ${ }^{38}$. W zrzutach materiałowych dla Warszawy dostarczono jedynie 250 tys. $\mathrm{RM}^{39}$.

33 Rozbieżności co do wysokości kwot zrzuconych dla DR na kosze „Wilga” (22/23 XI 1944) i „Solnica” (18/19 XI 1944) (ibidem, s. 73, 74, 75, 77, 95; K. Bieniecki, op. cit., s. 321). DR meldowała w grudniu 1944 r., że nie otrzymała środków dostarczonych na te dwa kosze (W. Grabowski, Niedoręczona..., s. 95).

${ }^{34}$ WBH, OVI, II.52.545, Depesza nr 367 gen. Roweckiego z 14 X 1941, k. 66; Armia Krajowa $w$ dokumentach 1939-1945, t. I: Wrzesień 1939 - czerwiec 1941, Wrocław 1990, s. 503-505; Instrukcja nr 8, w: Armia Krajowa $w$ dokumentach..., t. II: Czerwiec 1941 - Kwiecień 1943, Wrocław 1990, s. 78.

${ }^{35}$ Armia Krajowa $w$ dokumentach..., t. II, s. 147; Instrukcja nr 10, w: Armia Krajowa $w$ dokumentach..., t. II, s. 175.

${ }^{36}$ Polskie Sity Zbrojne..., s. 344.

${ }^{37}$ W. Grabowski, Polska tajna administracja cywilna 1940-1945, Warszawa 2003, s. 175.

${ }^{38}$ K. Bieniecki, op. cit., s. 276, 293.

${ }^{39}$ Zrzut dokonany w nocy 10/11 IX 1944 r. Środki były przeznaczone dla Delegatury Rządu na Kraj. Pierwotnie miały zostać zrzucone nad Warszawa, jednak z powodu nie odnale- 
Wykres 2. Skala przerzutu łącznością lotniczą środków finansowych (kwoty w tys.) dla AK i DR ${ }^{40}$

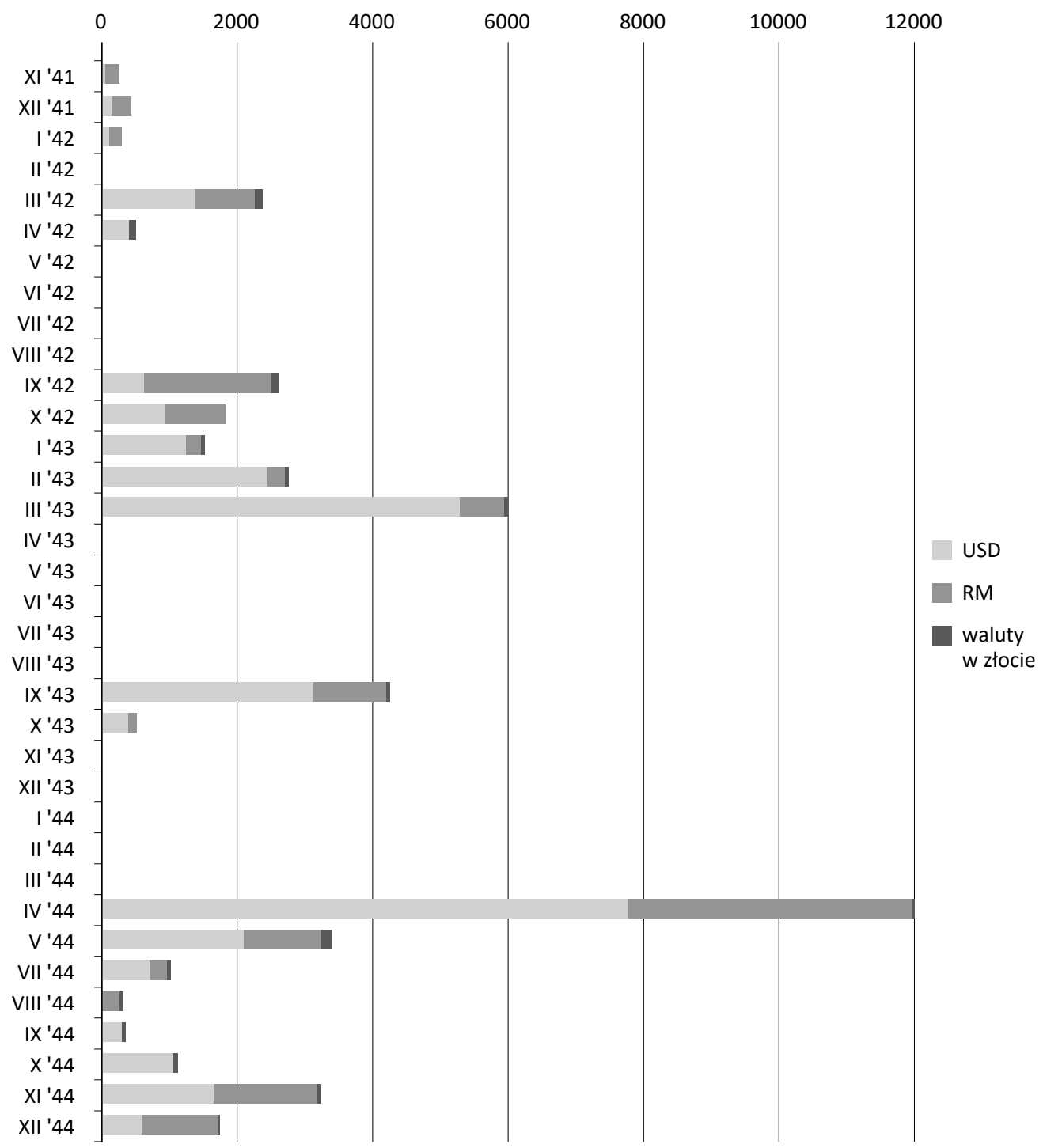

zienia miejsca zrzutu przez załogę samolotu zasobniki z pieniędzmi zrzucono w Puszczy Kampinoskiej. Zob. SPP, OVI, A141, k. 62; K. Bieniecki, op. cit., s. 280-281.

40 Powyższy wykres wymaga komentarza. Przy jego układaniu wzięte pod uwagę zostały maksymalne kwoty, jakie mogły być przerzucone w danym zrzucie. Rozbieżności w kwotach ukazałem w tabeli 2. Wykres został poprowadzony od listopada $1941 \mathrm{r}$., czyli od momentu, w którym nawiązano łączność lotniczą między Anglią a Polską (zrzut próbny z 15/16 II 1941 pominięty z uwagi na przejrzystość tabeli - środki dostarczone w tym zrzucie ujęte w tabeli 2). W zestawieniu nie umieszczono także wysłanych do kraju „młynarek” (głównie w sezonie „Riposta”), gdyż trudno ustalić, jakie kwoty młynarek zostały przekazane do Polski 
Przerzut pieniędzy dla AK i DR oparto na obcych walutach, głównie dolarach, które stosunkowo łatwo pozyskiwano w Anglii, w mniejszym stopniu na markach niemieckich. Waluty obce zabierały znacznie mniej miejsca i przesyłka ich była prostsza niż złotówek ${ }^{41}$. W $1941 \mathrm{r}$. gen. Rowecki zgłaszając zapotrzebowanie na budżet dla ZWZ w wysokości 500 tys. USD, zastrzegał, aby $50 \%$ tej sumy pochodziło ze złotych dolarów ${ }^{42}$. Na przeszkodzie realizacji tych zamierzeń stanęły względy techniczne. Masa złota była zbyt duża, by można prowadzić zrzuty walut $\mathrm{w}$ tym kruszcu na szerszą skalę. $\mathrm{Z}$ tego względu wartość nominalna walut w złocie nie przekroczyła 5\% wartości wszystkich pieniędzy przerzuconych. Przez całą okupację bazowano więc na banknotach papierowych.

Przesyłanie do kraju waluty, która nie była głównym środkiem płatniczym w Generalnym Gubernatorstwie, generowało szereg trudności ${ }^{43}$. Skala wymiany dolara na czarnej giełdzie przez AK powodowała raptowną zniżkę jego wartości. W tej sytuacji Oddział VI Sztabu NW sugerował w połowie 1942 r. organizowanie wymiany „na prowincji” lub w Berlinie ${ }^{44}$. Nie udało mi się jednak natrafić na jakiekolwiek ślady podjęcia przez AK takich działań. Przypuszczam, że nie zrealizowano sugestii Sztabu NW. Wszak przerzucenie znacznych kwot pieniędzy przez granicę rodziłoby spore trudności organizacyjne i skutkowałoby znacznymi stratami części przerzucanych sum, tak jak miało to miejsce z przerzucaniem środków pieniężnych przez kurierów trasami lądowymi.

Pomimo okresowego spadku kursu dolara papierowego, cena dolara złotego utrzymywała się na wysokim poziomie. W październiku $1941 \mathrm{r}$. relacja ceny dolara w złocie do dolara papierowego wynosiła 1 do 2 , zaś w maju 1942 r. już prawie 4 do $1^{45}$. Sytuacja uległa zmianie w momencie rozpoczęcia likwidacji

w poszczególnych zrzutach. Co istotne w wypadku akcji zrzutowej przeprowadzonej w maju 1944 r., udało mi się skompletować jedynie część kwot przerzucanych do kraju (opisane $\mathrm{w}$ tabeli 2). $\mathrm{Z}$ tego powodu dane zawarte w wykresie, dotyczace waluty w banknotach, moga być różne od faktycznego stanu dostarczonych środków. Na podstawie wyników z poszczególnych miesięcy sezonu „Riposta”, odejmując je od globalnej kwoty przerzuconej w tym okresie do kraju, oszacowałem, że w maju 1944 r. do ZWZ-AK trafiło 3883,7 tys. USD i 1230,5 tys. RM. Nie znamy więc przydziału do poszczególnych ekip 1760,7 tys. USD i 80,5 tys. RM z tej kwoty, czyli aż 40\% przerzuconych w tym miesiącu środków. Oznacza to, że skala przerzutu pieniędzy w maju $1944 \mathrm{r}$. była najprawomocniej zbliżona do tej z marca $1943 \mathrm{r}$.

${ }^{41}$ Meldunek nr 2 do Komendanta Głównego ZWZ, w: Armia Krajowa $w$ dokumentach..., t. I, s. 83.

${ }^{42}$ Radiogram M2M oraz radiogram nr 199, w: Armia Krajowa $w$ dokumentach..., t. I, s. 366, s. 467.

${ }^{43}$ KG AK pod koniec kwietnia 1942 r. wnioskowała o dostarczanie funtów, dolarów i rubli złotych. Franki i korony szwedzkie uznano za trudne do wymiany. Wnioskowano także o przysyłanie banknotów dolarowych wyemitowanych przed 1926 r., z uwagi na łatwiejsza możliwość ich wymiany na czarnym rynku. WBH, OVI, II.52.555, Depesza Kaliny nr 348 z 27 IV 1942 r., k. 34.

${ }^{44}$ WBH, OVI, II.52.615, Depesza Rawy nr 2385, k. 262.

${ }^{45}$ WBH, OVI, II.52.555, Depesza Kaliny nr 363 z 3 V 1942 r., k. 45. 
małego getta w Warszawie. Wydarzenie to wstrząsnęło czarnym rynkiem. W sierpniu $1942 \mathrm{r}$. cena dolara papierowego w getcie wynosiła $23 \mathrm{zl}$, a po stronie ,aryjskiej” - 28 zł. Oszacowano, że w 1942 r. wartość dolara spadła o $50 \%$, podczas gdy ceny wzrosły średnio o $150 \%{ }^{46}$. W 1943 r. zanotowano kolejny spadek ceny dolara, związany z likwidacja getta. Już w okresie likwidacji małego getta w kręgach dowódczych AK wzrosła obawa o dalsza możliwość wymiany dolarów na młynarki ${ }^{47}$. W związku z tym proszono o zwiększenie ilości przysyłanych marek i przyśpieszenie druku fałszywych młynarek. Pomijając okresowe wahania ceny dolara, jego wartość w czasie okupacji stale wzrastała. Na początku $1944 \mathrm{r}$. cena dolara wynosiła $150 \mathrm{z} 4^{48}$. W połowie tego roku oscylowała na poziomie $190-200 \mathrm{zł}$ za banknot studolarowy i $220-230$ zł za niższe nominały ${ }^{49}$. Tendencja ta została zobrazowana na wykresie 3, uwzględniającym ceny dolara w poszczególnych latach okupacji.

Środkiem zaradczym pozwalającym na uniknięcie negatywnych skutków wahań ceny waluty na czarnym rynku było przysyłanie do kraju zwiększonej ilości funduszy. Doliczenie do budżetu AK nadwyżki środków przewidzianych na amortyzację wahań kursu dolara i marki pozwalało realizować przez AK działania, bez większych obaw o ich zabezpieczenie finansowe.

\section{Wykres 3. Cena dolara na czarnym rynku w poszczególnych latach okupacji ${ }^{50}$}

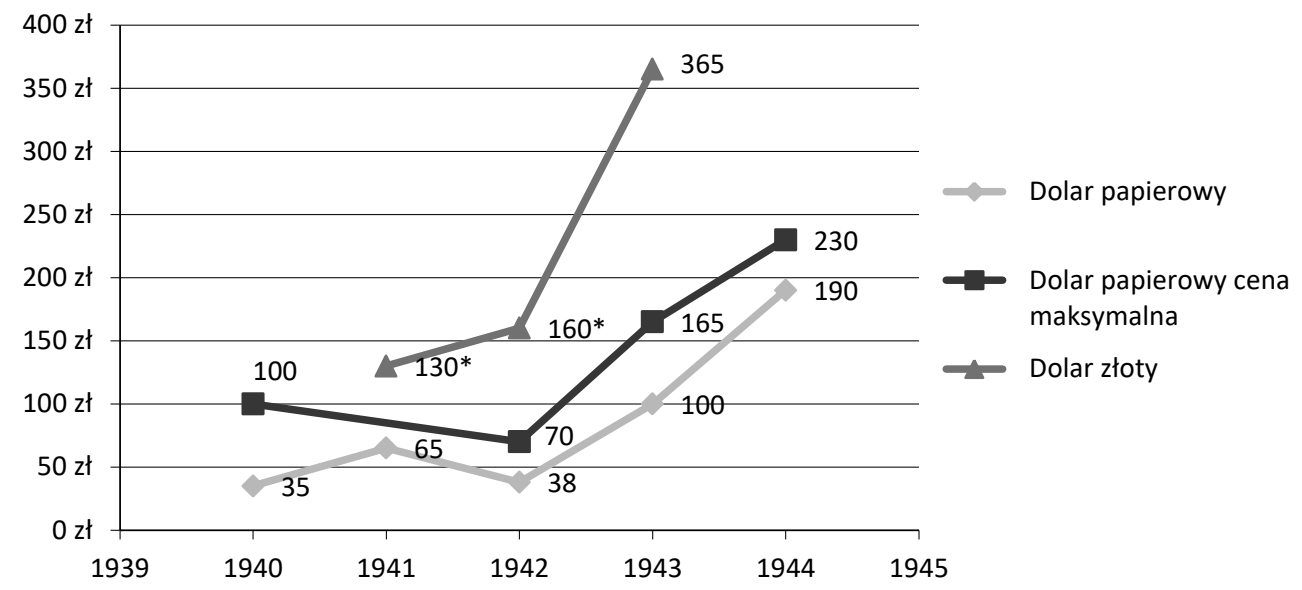

* Cena oszacowana na podstawie relacji walut względem siebie w danym okresie.

${ }^{46}$ Polskie Sity Zbrojne..., s. 347.

${ }_{47}$ WBH, OVI, II.52.559, Depesza Kaliny nr 598 z 31 VII 1942 r., k. 81.

${ }_{48}$ Armia Krajowa w dokumentach..., t. III: Kwiecień 1943 - lipiec 1944, Wrocław 1990, s. 287.

${ }^{49}$ Polskie Sity Zbrojne..., s. 327, 347.

${ }^{50}$ Na podstawie: WBH, OVI, II.52.545, k. 74; WBH, OVI, II.52.559, k. 81; WBH, Ruch Oporu, IX.3.21.26, k. 1; Armia Krajowa $w$ dokumentach..., t. III, s. 287; Polskie Sity Zbrojne..., s. 327, 347; W. Bartoszewski, 1859 dni Warszawy, Kraków 1974, s. 103, 342-343, 345; B. Szyprowski, Kradzież..., s. 214. 
Wobec problemów z wymiana dolara na czarnym rynku oraz mniejszej ilości przerzucanych do kraju marek niemieckich coraz silniej jawiła się potrzeba dostarczenia dla AK i DR młynarek. Próby sfałszowania waluty obowiązującej w GG podejmowano na zachodzie już od 1942 r. ${ }^{51}$ Jednak powodzenie w tym zakresie uzyskano dopiero w $1943 \mathrm{r}$. W marcu $1943 \mathrm{r}$. zrzucono 700 tys. sfałszowanych złotych, aby AK mogła ocenić jakość ich wykonania w Anglii ${ }^{52}$. Sfałszowane pieniądze ocenione zostały jako nienadające się do wprowadzenia do obiegu ${ }^{53}$. Przełom nastapił w połowie $1943 \mathrm{r}$. W lipcu $1943 \mathrm{r}$. do Anglii, przez bazę w Budapeszcie „Liszt”, dotarł kurier, który dostarczył kliszę banknotów 50, 100 i 500 zł oraz próby papieru, znaków wodnych i farb stosowanych do ich wytwarzania ${ }^{54}$.

W listopadzie 1943 r. szef Oddziału VI (Specjalnego) Sztabu NW ppłk M. Protasewicz „Rawa” meldował gen. Tadeuszowi Komorowskiemu gotowość do wysyłki do kraju 50 mln złotówek w nominale 500 zł oraz $80 \mathrm{mln}$ złotówek w nominale $100 \mathrm{z}^{55}$. Nie udało mi się dotrzeć do większej liczby dokumentów przedstawiających przerzut tej waluty do kraju w poszczególnych lotach. Jest wysoce prawdopodobne, że większość przerzuconych młynarek została dostarczona w kwietniu i maju 1944 r. ${ }^{56}$ Warto nadmienić, że jeszcze przed zainicjowaniem na dużą skalę przerzutu młynarek drogą lotnicza AK „wzbogaciła się” o 105 mln młynarek pozyskanych w akcji „Góral” ${ }^{2}$. Przesyłanie więc większej liczby fałszywych młynarek nie stanowiło priorytetu w zrzutach w sezonie „Odwet”. Przestrzeń ładunkowa mogła być zagospodarowana na przerzut marek niemieckich i dolarów. Sfałszowane młynarki znajdowały się w zrzucanych paczkach, głównie w okręgach Kraków, Kielce, Lublin i Obszarze Warszawskim i były tam pozostawiane jako „depozyt” $\mathrm{KG} \mathrm{AK}^{58}$. Z zachowanych dokumentów wynika, że w ostatnim

${ }_{51}$ WBH, OVI, II.52.615, Depesza Rawy nr 4811, k. 123.

${ }^{52}$ SPP, OVI, A421, k. 171, 173. Młynarki zrzucono w paczkach na kosze „Jawor”, „Jajo”, „Gęś”, „Smok”.

${ }^{53}$ Ibidem, k. 170.

${ }^{54}$ K. Stoliński, op. cit., s. 6.

${ }^{55}$ Ibidem, s. 7.

${ }^{56}$ Loty w sezonie operacyjnym „Riposta” od listopada do grudnia były prowadzone w ograniczonym zakresie (5 zrzutów). Dopiero od kwietnia 1944 r. nastapiła ich intensyfikacja (kwiecień - 32 zrzuty, maj - 52 zrzuty) (K. Bieniecki, op. cit.). Do 29 V 1944 r. przerzucono do kraju 34 429,8 tys. zł, więc większość dostarczonych do kraju młynarek (K. Stoliński, op. cit., s. 7).

${ }^{57}$ Szerzej o jej przebiegu zob. E. Kumor, Wycinek z historii jednego życia, Warszawa 1969, s. 139-180; T. Strzembosz, Akcje zbrojne podziemnej Warszawy 1939-1944, Warszawa 1983; A. Żupański, Kryptonim „Góral”. Brawurowa akcja AK-zdobycie 100 milionów złotych, Warszawa 2009; S. Smarzyński, Akcja „Góral”, Lublin 1973.

${ }^{58}$ Instytut Pamięci Narodowej, Biuro Udostępniania, 397/230/1, K. Pluta-Czachowskiego, Organizacja zrzutów lotniczych w b. AK (krypt. „Syrena”). Zarys odtworzony z pamięci. Zeznania własne, Warszawa 15 VII 1949 r., s. 5. 
sezonie operacyjnym dostarczono m.in. ponad $3 \mathrm{mln}$ zł wraz ze zrzutem skoczków z ekipy „Kruka-2” na bastion „Rozmaryn-2” (21/22 IX 1944) ${ }^{59}$ oraz w zrzucie materiałowym na bastion „Kobuz”, przeprowadzonym tej samej nocy (880 tys. $\mathrm{zł}^{60}$ ). Co jest dość intrygujące, zważywszy na brak wyszczególnienia tej waluty w sprawozdaniach Oddziału VI (Specjalnego) za ten sezon operacyjny.

Sprawne odebranie zrzutu przez konspirację stanowiło jedynie wstępny sukces. Pozyskane ze zrzutu pieniądze trzeba było jeszcze przerzucić i przekazać do dyspozycji Oddziałowi IV (Kwatermistrzostwo) KG. Często zdarzało się, że odebranie jednego zrzutu oznaczało kilka wyjazdów w teren, by przekazać zrzucone pieniądze ${ }^{61}$. W efekcie środki pieniężne dostarczone do kraju były dostępne dla KG AK dopiero po pewnym czasie od zrzutu. Dla przykładu ostatnie ewakuacje pieniędzy ze zrzutów przeprowadzonych w marcu 1943 r. zakończyły się w czerwcu tego roku ${ }^{62}$. W sytuacji, gdy środki pieniężne posiadały wraz ze skoczkami wysoki priorytet w ewakuacjach ${ }^{63}$, organizowanie przerzutu pieniędzy od razu powierzano komórce zrzutów KG $\mathrm{AK}^{64}$. Od września 1943 r. wraz z decentralizacją odbioru zrzutów do końca wojny wprowadzono zasadę, że zawartość ładunków przypadała okręgom, do których je kierowano. Zrzuty do dyspozycji KG były wysyłane w rejon Warszawy (Okręg Warszawa i Obszar Warszawski) ${ }^{65}$.

W czasie ewakuacji dochodziło do utraty części przerzuconych środków. 26 II 1943 r. w czasie jednej z ewakuacji żandarmerii niemieckiej udało się przejąć pieniądze zrzucone na placówkę „Koń” (16/17 II 1943) ${ }^{66}$. Utracono wtedy 81 tys. USD przeznaczonych dla DR i 315 tys. USD wysłanych

${ }^{59}$ K. Bieniecki, op. cit., s. 287; SPP, OVI, A141, k. 62.

60 SPP, OVI, A141, k. 62.

${ }^{61}$ Szereg ewakuacji, głównie środków pieniężnych, opisał w swoich wspomnieniach oficer komórki zrzutów - por. Aleksander Stromenger „Lebera” (A. Stromenger, Człowiek z zakalcem, Warszawa 1970).

${ }^{62}$ Ibidem, s. 131.

${ }^{63}$ SPP, OVI, A141, k. 18.

${ }^{64}$ Powstała jako zespół „komórka” w tworzonym od wiosny 1940 r. tzw. dowództwie lotnictwa (później Wydział Lotniczy w Oddziale III KG). Od jesieni lub przełomu 1941 i 1942 r. komórka zrzutów, która rozrosła się w tym czasie do wielkości referatu, została podporządkowana Oddziałowi V KG. Od jesieni 1942 r. rozrosła się do Wydziału Przerzutów Powietrznych (etat: 100 osób, w rzeczywistości 50-60 osób). Latem 1943 r. kadry Wydziału posłużyły do tworzenia referatów pp w Okręgach i Obszarach AK (powstałych w Obszarze Warszawskim, Obszarze Lwów, Okręgu Warszawa, Okręgu Radom, Lublin, Kraków Wołyń; a w 1944 r. w Obszarze Północno-Wschodnim, Okręgu Łódź, Śląsk). Komórka zrzutów została rozbita w Powstaniu Warszawskim. Część jej oficerów zasiliła odtwarzaną w Częstochowie KG AK (Referat Przerzutów Powietrznych Samodzielnego Wydziału Lotnictwa KG AK). Działała do sierpnia $1945 \mathrm{r}$.

${ }^{65}$ K. Iranek-Osmecki, Powołanie i przeznaczenie. Wspomnienia oficera Komendy Gtównej AK 1940-1944, Warszawa 2004, s. 311.

${ }^{66}$ Szerzej o okolicznościach tego wydarzenia zob. J. Tucholski, op. cit., s. 145. 
dla $\mathrm{AK}^{67}$. Była to jedna z największych, jeżeli nie największa, sum pieniędzy zdobytych przez Niemców w czasie akcji ewakuacyjnych. Zachowane relacje i meldunki nie pozwalają nam nawet w przybliżeniu oszacować, jaka część pieniędzy została utracona w czasie transportu i denuncjacji skrytek i magazynów AK. W próbnym sezonie operacyjnym AK oszacowała poniesione straty na 95165 USD i 4422 USD w złocie (kosz „Polec” 3/4 III 1942, „Trawa” 27/28 III 1942, „Błoto” - zrzut dziki - 30/31 III 1942, „Kopyto” 30/31 III 1942, „Łaka” 8/9 IV 1942) ${ }^{68}$.

Znane są nam dane dotyczące utraty środków pieniężnych w drodze do kraju. Jak meldował gen. Stefan Rowecki w 1942 r.: „,...] straty na tej drodze [zrzutów - G.R.] sa znacznie mniejsze /około 3\%/, niż na drodze kurierskiej /około 30\%/. Będą niewątpliwie jeszcze bardziej zmniejszone, jeżeli usprawnicie zrzuty a my odbiór na placówce" ${ }^{69}$. W akcji zrzutowej nie udało się jednak zmniejszyć strat przewożonych pieniędzy. Oddział VI oszacował, że w sezonie próbnym utracono 7\% USD w złocie i nieustaloną liczbę $\mathrm{RM}^{70}$, w kolejnym sezonie operacyjnym („Intonacja”) - 4\% przewożonych walut, zaś w sezonie operacyjnym „Riposta” - 7\% USD i $2 \% \mathrm{RM}^{71}$. W zamykajacym akcję zrzutową sezonie „Odwet” straty pieniędzy wynosiły $5 \% \mathrm{RM}^{72}$. Członkowie Komisji Historycznej b. Sztabu Generalnego oszacowali natomiast, że strata waluty pochodzącej ze zrzutów wynosiła ok. $10 \%{ }^{73}$. Pomimo tych strat zrzuty lotnicze okazały się najefektywniejszą formą dostarczenia pieniędzy dla konspiracji.

Zrzuty lotnicze stanowiły główne źródło zaopatrzenia AK i DR w waluty obce, na których opierała się gospodarka finansowa Polskiego Państwa Podziemnego (zob. wykres 4). Jedynie w przypadku złotych okupacyjnych lądowymi trasami kurierskimi dostarczono więcej środków (zob. wykres 4). Pomimo nakreślonych powyżej niedogodności należy ocenić, że sprawdziły się oczekiwania KG AK z 1942 r., dotyczące przerzutu lotniczego, który pozwolił na znaczne zaopatrzenie Sił Zbrojnych w Kraju w gotówkę ${ }^{74}$.

${ }^{67}$ K. Bieniecki, op. cit., s. 58; W. Grabowski, Niedoręczona..., s. 70. Tucholski podał, że utracono 396422 USD, 320 RM oraz walutę w złocie (350 USD, 277 franków, 40 rubli i $40 \mathrm{RM})$. Na sumę tę składały się prywatne pieniądze skoczków oraz środki przeznaczone dla AK i DR. Tucholski podawanych przez siebie sum pieniędzy nie opatrzył przypisem. Dane te trzeba więc traktować z większą ostrożnościa.

68 J. Tucholski, op. cit., s. 129.

${ }^{69}$ SPP, OVI, A420, k. 193.

70 J. Tucholski, op. cit., s. 129.

${ }^{71}$ Ibidem, s. 151.

72 Ibidem, s. 179.

${ }^{73}$ Polskie Sity Zbrojne..., s. 346.

${ }^{74}$ SPP, OVI, A420, Meldunek KG AK nr 133 (Sprawozdanie z łączności lotniczej za sezon 1941/42), k. 193. 


\section{Wykres 4. Udział pieniędzy zrzutowych w kwotach dostarczonych do ZWZ-AK (zaokrąglone kwoty w tys.) $)^{75}$}

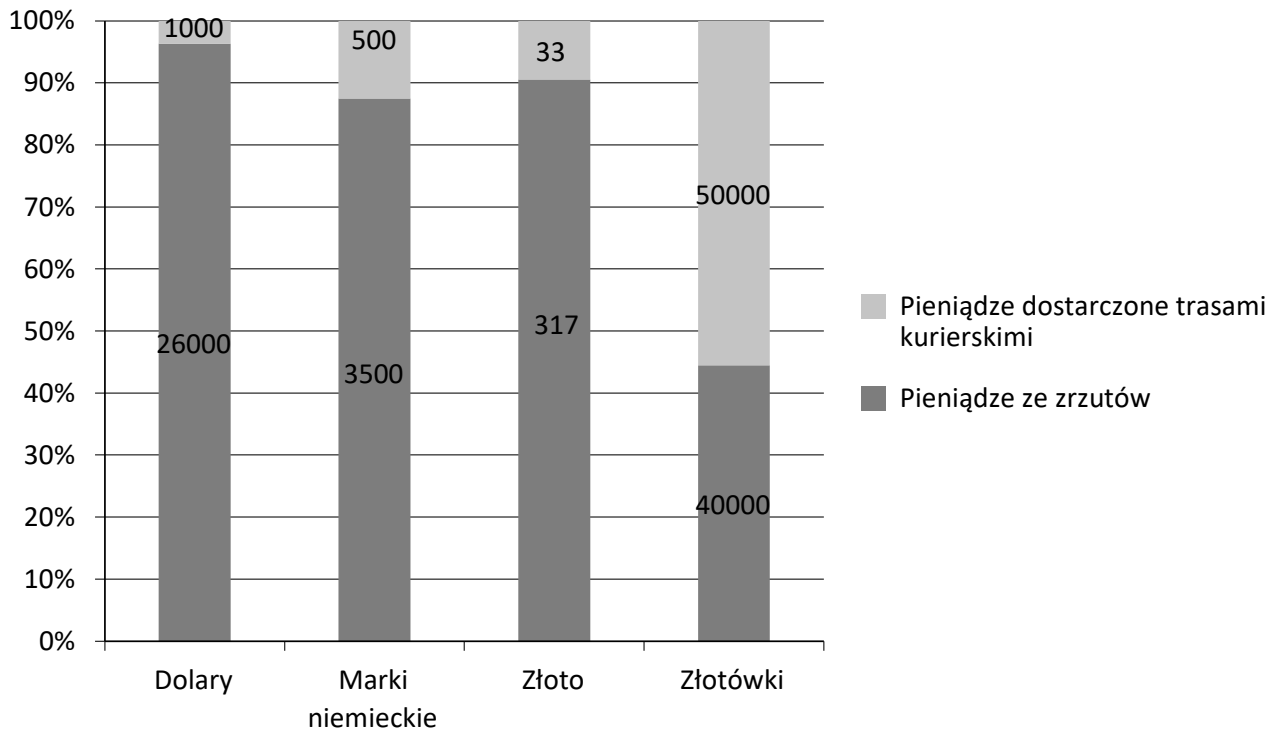

\section{Streszczenie}

W czasie II wojny światowej Siły Zbrojne w Kraju i cywilne struktury Polskiego Państwa Podziemnego otrzymały liczone w milionach dolarów wsparcie finansowe od władz polskich na obczyźnie. Na tych środkach opierała się gospodarka finansowa Polskiego Państwa Podziemnego. Większa część tych sum docierała do kraju wraz ze zrzutami lotniczymi prowadzonymi z Zachodu. Znane są globalne kwoty wysłane tą drogą. Artykuł stanowi próbę przedstawienia sum wysyłanych dla Armii Krajowej i Delegatury Rządu na Kraj w poszczególnych miesiącach okupacji.

W dostępnym materiale źródłowym występują nieścisłości utrudniające ustalenie dokładnych sum wysłanych do kraju. Co więcej, już w czasie wojny odnotowywano przypadki nieścisłości w prowadzonej ewidencji sum wysyłanych dla Polskiego Państwa Podziemnego.

Z pomocą finansową pochodzącą ze zrzutów lotniczych wiążą się zagadnienia wymiany obcych walut na czarnym rynku oraz zakrojona na szeroka skalę akcja fałszowania i wysyłania do kraju złotych okupacyjnych.

\section{Cash and Cash Equivalents Airdropped for the Polish Underground State}

During the Second World War, the Armed Forces in Poland and civilian structures of the Polish Underground State were given assistance counted in millions of dollars from the Polish Government-in-Exile. Those founds made the financial basis of the Polish Underground State. A major part of those money were airdropped. We know of total sums transferred to Poland via this channel. The text is an attempt to present the sums airdropped to the Home

${ }^{75}$ Polskie Sity Zbrojne..., s. 346. 
Army and the Government Delegation for Poland in particular months of the occupation. The available source material presents some imprecisions making it difficult to establish the exact sums sent to the country. What is more, already during the war there were some inaccuracies noted in the records of money transferred to the Polish Underground State. The subject of airdropped financial assistance is related to questions of currency exchange on the black market and a broad-scale action of forging occupation money and sending it to Poland under the occupation.

\section{Bibliografia}

Bieniecki K., Lotnicze wsparcie Armii Krajowej, Kraków 1994.

Grabowski W., Delegatura Rzqdu Rzeczypospolitej Polskiej na Kraj, Warszawa 1995.

Grabowski W., Niedoręczona poczta. Zrzuty lotnicze (finansowe i materiałowe) dla Delegatury Rzadu na Kraj, w: Żotnierzowi Niepodległej. Księga dedykowana śp. gen. Mieczystawowi Huchli, red. T. Balbus i in., Rzeszów 2012, s. 64-95.

Polskie Sity Zbrojne w drugiej wojnie światowej, t. III: Armia Krajowa, Londyn 1950.

Stoliński K., Pomoc finansowa dla Armii Krajowej i Delegatury Rzqdu na Kraj (1940-1944), „Mars” 2004, t. XVI, s. 5-14.

Szyprowski B., Kradziė̇ pieniędzy cichociemnych z placówki „Pole” pod Wyszkowem. Wyrok Wojskowego Sadu Specjalnego na Wtadystawa Wysockiego, „Rocznik Wołomiński” 2011, t. VII, s. 211-227.

Szyprowski B., Porucznik cc. Witold Strumpf „Sud” przed sqdem podziemia, „Przegląd Historyczno-Wojskowy” 2012, nr 2 (240), s. 207-218.

Tucholski J., Cichociemni, wyd. 3, Warszawa 1988.

Biog r a m: Grzegorz Rutkowski - mgr, doktorant w IH PAN, kurator w Muzeum Historii Polski. Zainteresowania badawcze: historia wojskowości, dzieje najnowsze ze szczególnym uwzględnieniem historii Polskiego Państwa Podziemnego. Ważniejsze publikacje: Udziat niemieckiej 4. dywizji pancernej w bitwie nad Bzura, „Rocznik Łowicki” 2010, t. VII. E-mail: grzegorz_rutkowski@vp.pl. 